\title{
ENTRE BIOLOGÍA Y ESPÍRITU. PENSAR (DESDE) LA CIENCIA - PENSAR (DESDE) LA VIDA: LA AVENTURA INTELECTUAL DEL BIÓLOGO ANDRÉS MOYA
}

\author{
DIEGO BERMEJO \\ Universidad de Deusto
}

\begin{abstract}
RESUMEN: Las ciencias de la vida, a la luz de la teoría de la evolución, están aportando, según A. Moya, un territorio mestizo que obliga a pensar desde la ciencia cuestiones que parecían patrimonio exclusivo de las humanidades: la naturaleza y sentido del ser humano y de la vida. Las preguntas metafísicas sobre el ser humano y la vida, propias de la tradición humanista, pasan ahora inexorablemente por la ciencia, por los hallazgos recientes en biología molecular y evolutiva, biogénetica, bioquímica, neurobiología, sociobiología, psicología evolutiva, biocomputerización, etc. Entre cientificismo antihumanista y humanismo espiritualista, entre el desprecio de las humanidades y el desprecio de las ciencias - desprecio basado en la ignorancia mutua y/o en presupuestos ideológicos -, cabe un cientismo humanista, fiel a la mejor tradición intelectual de nuestra cultura. Contra este desencuentro, poco ilustrado, Moya muestra su convencimiento de que se debe y se puede superar ese hiato profundo, a partir, sobre todo, de los avances que la biología evolutiva, y en general las ciencias de la vida, podrían proporcionar como territorio común sobre el que pensar y desde el que pensar tanto la misma ciencia como la vida, tanto el sentido de la ciencia como el sentido de la vida humana. La aventura intelectual de A. Moya se presenta como un ejemplo de honestidad y de rigor, abogando contra cualquier reduccionismo por mantener abiertas las tensiones creativas entre biología y espíritu.
\end{abstract}

PALABRAS CLAVE: Evolución; darwinismo; transevolución; transhumanismo; biofilosofía; espiritualidad; religión.

\section{Between Biology and Spirit.}

Thinking (from) Science - Thinking (from) Life.

\section{The Intellectual Adventure of the Biologist and Philosopher Andrés Moya}

ABSTRACT: The life sciences, in the light of the theory of evolution, are contributing, according to A. Moya, a mixed territory that forces to think from the science questions that seemed exclusive patrimony of the humanities: the nature and sense of the human being. The metaphysical questions about human beings and life, characteristic of the humanist tradition, now pass inexorably through science, recent findings in molecular and evolutionary biology, biogenetics, biochemistry, neurobiology, sociobiology, evolutionary psychology, biocomputerization, etc. Between anti-humanist scientism and spiritualist humanism, between the contempt of the humanities and the contempt of the sciences - scorn based on mutual ignorance and/or ideological presuppositions -, there is a humanistic scientism, faithful to the best intellectual tradition of our culture. Against this little illustrated disagreement, Moya shows his conviction that this deep chasm should and can be overcome, starting from the advances that evolutionary biology, and in general the sciences of life could provide as common base upon which to think and from which to think both science and life, both the sense of science and the meaning of human life. The intellectual adventure of A. Moya may be seen as an example of honesty and rigor, advocating against any reductionism for keeping open the creative tensions between biology and spirit.

KEY WORDS: Evolution; darwinism; transevolution; transhumanism; biophilosophy; spirituality; religion. 


\section{PENSAR (DESDE) LA CIENCIA}

INTRODUCCIÓN

«Algunos hombres se dedican a la ciencia, pero no todos lo hacen por amor a la ciencia misma». Andrés Moya merecería el elogio que Einstein dirigió a Max Planck en el prólogo escrito para el libro de éste, "¿A dónde va la ciencia? (1941). Andrés Moya, Premio Nacional de Genética 2012 y Premio México de Ciencia y Tecnología 2015, encarna el prototipo de intelectual con doble alma, científica y humanística; pero comprometido en buscar una síntesis que resuelva definitivamente el conflicto entre las «dos culturas» (pace Snow) que han partido el alma de Occidente ${ }^{1}$. Y ello por fidelidad a su doble vocación de científico y filósofo que en él se unifican, no sin tensiones o, precisamente, gracias a ellas, en línea con el mejor talante heurístico de la tradición socrática (continuar la pregunta hasta donde la pregunta lleve) y la tradición aristotélica (dar razón de los fenómenos); y, en el caso de un biólogo evolucionista como Moya, dar razón del fenómeno singular de la aparición de la vida autoconsciente que busca razón de sí misma y de su propia ocurrencia en el proceso de la evolución natural. En él se recupera el prototipo clásico del filósofo de la naturaleza, humanista/ científico, figura paradigmática en nuestra cultura occidental desde sus albores presocráticos y lamentablemente demediada en la modernidad reciente. La pasión por el conocimiento y la verdad pertenecen a nuestro genoma cultural. La ciencia, según Moya, fiel al viejo ideal de la tradición filosófica/científica griega, intenta «explicar lo inefable», desvelar lo implícito, descubrir la verdad. La ciencia encarna en ella misma el ideal de la aletheia griega: desvelar el logos, la razón profunda de las cosas y su sentido. La ciencia seria piensa, pretende comprensión global, no solo explicación parcial. Recuperar este auténtico pathos filosófico para la ciencia exige reincrustarla en las coordenadas de la transdisciplinariedad y de la complejidad. Exigencia mayor, si cabe, para las ciencias de la vida, a las que se añade como objeto de estudio la complejidad propia del origen y evolución del animal humano. Postula una síntesis de la tradición humanística y filosófica, a partir del nuevo marco epistémico proporcionado por la teoría de la evolución, que permita una relectura de sus contenidos tradicionales desde una nueva perspectiva evolucionista. Utiliza los conceptos de ciencia prometeica y de ciencia faústica para intentar armonizar la distinción —necesaria aunque inseparable en la praxis de la ciencia actualentre una ciencia más filosófica, la primera, guiada por la búsqueda incansable

1 Vide estudios previos dedicados al pensamiento de A. Moya, in: Bermejo, D., «Las aventuras del paradigma antrópico: humanismo, posthumanismo y transhumanismo», in: Bermejo, D., Pensar después de Darwin. Ciencia, filosofía y teología en diálogo, Sal Terrae, Santander, 2014, pp. 13-106; Bermejo, D., «Exordio: Andrés Moya, un científico melancólico», in: Moya, A., Biología y Espíritu, Sal Terrae, Santander, 2014, 7-41. 
y honesta de la verdad, que aspira a la comprensión global de la realidad y a responder a las cuestiones existenciales y éticas del ser humano (voluntad de saber); y una ciencia más pragmática, la segunda, orientada a la aplicación práctica del conocimiento y a la intervención transformadora en el mundo, más sometida a imperativos tecnoeconómicos y sociopolíticos (voluntad de poder). Moya reivindica al científico como intelectual comprometido y propone regenerar la ciencia, porque - afirma-: «Intuyo que exite algo esencialmente equivocado en la forma en cómo se desarrolla la ciencia actual. Al mismo tiempo tengo la necesidad de comunicar esta reflexión, la de plantear una ciencia regenerada, cierta vuelta comprometida al origen $»^{2}$.

\section{ENTRE DOS SENSIBILIDADES CIENTÍFICAS: ANTIHUMANISMO Y ANTROPISMO}

Se nos antoja que el científico actual se mueve en un arco de sensibilidades que, evidentemente con matices, va del antihumanismo al antropismo. En esa tensión se mueve el pensamiento de Moya: la ciencia muestra la insignificancia del ser humano en el cosmos, pero al mismo tiempo la ciencia muestra el significado del ser humano en el cosmos y el significado del mismo cosmos.

- Como ilustración del primer talante, más frecuente entre biólogos, valga la recurrente cita de Dawkins: «El universo que observamos tiene precisamente las propiedades que deberíamos esperar si, al final, no hay ni diseño, ni propósito, ni mal ni bien, nada más que indiferencia ciega e inmisericorde» ${ }^{3}$. Esto es lo que cabe esperar siguiendo la estela marcada por Monod: «... el hombre sabe al fin que está solo en la inmensidad indiferente del Universo del que ha emergido por azar. Su deber, no más que su destino, no está escrito en ninguna parte» ${ }^{4}$. También sostiene esta idea algún físico como Weinberg, cuando resume de forma lapidaria: «The more we comprehend the universe, the more pointless it seems $»^{5}$. Hijos desencantados de Darwin, testigos insignificantes de la grandeur fundada sobre un azar indiferente a la suerte de lo humano y su destino. Y lúcidos por nihilistas. La naturaleza no habla en lenguaje humano... la vida no tiene otro sentido más allá de la autorreproducción y autoconservación. El ser humano es un fruto azaroso, cuya ocurrencia no tendría especial sentido en sí misma. Surgido a la existencia y condenado a la insignificancia, se ve obligado a enfrentarse inexorablemente a la pregunta sobre sí mismo,

2 Moya, A., Pensar desde la ciencia, Trotta, Madrid, 2010, p. 79. Bibliografía de A. Moya al final del texto.

3 "The universe we observe has precisely the properties we should expect if there is, at bottom, no design, no purpose, no evil and no good, nothing but blind, pitiless indifference", Dawkins, R., River out of Eden, Basic Books, New Yor, 1995, pp. 131-132.

4 "L'ancienne alliance est rompue: l'homme sait enfin qu'il est seul dans l'immensité indifférente de l'Univers d'où il a émergé par hasard. Non plus que son destin, son devoir n'est écrit nulle part. A lui de choisir entre le Royaume et les ténèbres», Monod, J., Le hasard et la nécessité, Ed. du Seuil, Paris, 1970, p. 224.

5 Cit. in: Kauffman, S. A., Reinventing the sacred, Basic Books, NY, 2010 [2008], p. 10. 
la vida y el cosmos, y a responderla, bien negándole sentido como ilusión o bien afirmando su sentido como gesto infundado y pasión inútil condenada al nihilismo y/o al existencialismo trágico al que se ve abocado el animal humano, inexplicablemente condenado a la paradoja de saberse libre y determinado por un juego caprichoso que la naturaleza juega consigo misma, sin motivo, sin razón y sin sentido. A lo más, teleología funcional, adaptación penosa, mascarada de libertad, arbitrariedad génica...

Una cuestión queda sin responder en esta actitud: valor y sentido de la ciencia en relación con la racionalidad de lo real. Que la ciencia no pretende reducirse a entretenimiento o pasatiempo lo demuestra, primero, la seriedad con que la praxis científica entiende el juego del conocimiento y su voluntad de acertar, al menos, con la explicación de las cosas (funcionamiento causal) cuya comprensión definitiva (desvelamiento alético) encomienda a la confianza indubitable concedida al método científico; y, segundo, el carácter vocacional de la consagración a la actividad científica y su capacidad heurística, en ningún caso puro pasatiempo o mero empleo. Se cree que la ciencia pretende algo más que servir a intereses determinados por la voluntad de poder y se cree en la ciencia como búsqueda de la verdad (pretensión enfática que subyace implícita en el ejercicio serio de la vocación científica, erigida en la modernidad como subrogado secularizado de la pretensión teológica de verdad a la que trata de reemplazar como garante de la racionalidad de lo real).

Esa pregunta por el sentido holístico de la realidad, de la vida y del cosmos, que ha anidado filogenéticamente en el animal humano y ha encontrado acomodo tradicional en las religiones, reclama una respuesta. La ciencia debería llenar o haber llenado ya con más racionalidad el vacío dejado en la cultura por los procesos modernos de secularización de la cosmovisión teológica y haber satisfecho de modo científico la demanda de sentido, o haber demostrado cumplidamente su impertinencia. No parece que los intentos dawkinsianos surtan tal efecto, a tenor de las críticas recientes recibidas por colegas ateos que piden algo más que ideología o reduccionismo a la ciencia [ver Kauffman, Nolte, Sheldrake, etc.]. Si la ciencia pretendiera agotar el contenido semántico del concepto de verdad y convertirse así en reemplazo superador de la religión y la metafísica tradicionales, pretendiendo que la verdad científica otorgue sentido a la realidad, debiera - para ser realmente efectiva - convertirse en una nueva religión -o algo muy parecido a ella-; o, declarar un sinsentido la cuestión del sentido, pero rebajando entonces las pretensiones de verdad/sentido de la ciencia a propuestas siempre falsables y negando por tanto sentido enfático a la misma verdad científica. En cuyo caso, no cabría esperar del método científico afirmaciones definitivas sobre nada, siguiéndose como consecuencia lógica la humildad intelectual, convertida en búsqueda permanente e insaciable sin garantía alguna de descanso intelectual en ningún fundamento último ni para la ciencia ni para el científico, que se ve condenado así a la melancolía y la desesperanza existenciales.

Arrojado a la nada (Sartre), tiene que habérselas, sin embargo, con la extrañeza de una pregunta que debe interpretar como ilusión/espejismo 
insignificante, sin consistencia real, y como estrategia predeterminada por la astucia de los genes al servicio de su autorreproducción. Lo que la tradición humanista y filosófica en general ha considerado más distintivo de la condición humana (conciencia y libertad) quedaría reducido a una estrategia adaptativa determinada por la misma naturaleza ciega, guiada por los replicadores génicos, mientras vivimos dramáticamente la conciencia de sabernos juguete de un destino caprichoso y marionetas conducidas por una naturaleza indiferente a nuestra suerte. Pero que, paradójicamente, en la ignorancia del propósito oculto de la naturaleza, el ser humano puede experimentar la extraña libertad que quien juega sabiendo que juega (Nietzsche) en el espíritu de la libertad más pura, el espíritu del juego liberado de guión y finalidad ( «su deber como su destino no están escritos en ninguna parte» — pace Monod—; porque, si lo están, lo ignora o no se le imponen ostensivamente). La filosofía existencialista (que parece extenderse en el ámbito de los profesionales de la ciencia) hizo de la nada y del sinsentido el nicho de la libertad, pero la ciencia antihumanista convierte las elecciones humanas en epifénomenos de lo dictado por intereses predeterminados, sin explicar la paradoja en que se incurre al afirmar al mismo tiempo la conciencia de libertad y la predeterminación de las elecciones. He ahí la paradoja: la mayor libertad (existencial) deviene consecuencia del mayor determinismo (ontológico), y, en ese caso, la libertad queda negada a la vez que se afirma. La Naturaleza Impersonal, deificada, engendra a sus hijos, teje su destino, dirige sus voluntades para engullirlos finalmente sin razón. La tragedia griega dio bellísima cuenta de esta tensión existencial que se sigue de la lucidez del sinsentido y la fatalidad del destino. La mayor autonomía consecuencia de la mayor heteronomía. La ciencia se convierte entonces en aliada del nihilismo, en reveladora del fatal destino a que arroja la Naturaleza a la condición humana, a la inconsistencia, la futilidad y el sinsentido.

- Como ilustración del segundo talante, más frecuente entre físicos, valga a su vez esta larga cita de Paul Davies: «La revolución que comenzó con Copérnico y terminó con Darwin, tuvo el efecto de marginar y aún trivializar los seres humanos. La gente no estaba ya en el centro del gran esquema (proyecto, plan, diseño), sino que fue relegada a un rol incidental (fortuito) y aparentemente sin sentido en un drama cósmico indiferente... Esta ética existencialista de que no hay significado en la vida humana más allá que el que los humanos mismos habían puesto en ella, se tornó el leitmotiv de la ciencia... //... presentaré una visión completamente diferente de la ciencia. Lejos de exponer a los seres humanos como el producto incidental de ciegas fuerzas físicas, la ciencia sugiere que la existencia de los organismos conscientes es una característica fundamental del universo. Hemos sido inscritos en las leyes de la naturaleza de una forma profunda, y yo creo, significativa... La ciencia es una búsqueda noble y enriquecedora que nos ayuda a encontrar el sentido del mundo de una forma objetiva y metódica. No niega un significado detrás de la existencia...//... A través de los seres conscientes el universo ha generado autoconciencia. Esto no puede ser un detalle trivial, el universo no es un subproducto menor de fuerzas sin propósito y sin sentido. Estamos pensados para estar aquí [«the 
universe is no minor byproduct of mindless, purposeless forces. We are truly meant to be here»]...// ... «Pertenezco al grupo de científicos que no se incribe en ninguna religión convencional, pero no obstante niega que el universo sea un accidente sin propósito. A través de mi trabajo científico he llegado a creer más y más fuertemente que el universo ha sido ensamblado con un ingenio tan asombroso que no puedo aceptar que es meramente un hecho bruto. Debe haber, me parece, un nivel más profundo de explicación. Si uno quiere llamar a ese nivel más profundo "Dios" es una cuestión de gusto o definición. Más áun, he llegado al punto de vista de que la mente, el conocimiento consciente del mundo, no es un accidente sin sentido de la naturaleza, sino una faceta absolutamente fundamental de la realidad. Esto no quiere decir que nosotros seamos el propósito por el cual el universo existe. Lejos de mí. Creo, no obstante, que nosotros, seres humanos estamos contruidos dentro del esquema de las cosas de una manera muy fundamental $»^{6}$. Y, por ello, la conciencia ilumina el cosmos y la ciencia trata de dar razón de sus secretos. Esta convicción deviene sentido para la existencia del ser humano en el mundo. En esta actitud cabe reconocer el élan humanista, demasiado antropocéntrico, del primer Diderot que afirmaba: «...si se destierra al hombre o al ser pensante y contemplativo de sobre la faz de la tierra, este espectáculo patético y sublime de la naturaleza no es más que una escena triste y muda. El universo se calla, el silencio y la noche se apoderan de él. Todo se transforma en una vasta soledad donde los fenómenos observados ocurren de una manera oscura y sorda. Es la presencia del hombre la que convierte en interesante la existencia de los seres"7. Esta postura antrópica por noológica permanece en la tradición humanista que reclama no solo singularidad para el ser humano, sino también algún tipo de centralidad en el cosmos, si no física o biológica, al menos noológica (el ser humano como conciencia de la naturaleza o naturaleza consciente de sí misma). Hijos de un humanismo racionalista que exige significado a la presencia del ser humano en el cosmos, precisamente a través y a partir de la razón científica que lo ilumina. Lúcidos por racionalistas... La naturaleza habla en lenguaje humano.

Ninguna de las dos posturas implica espiritualismo, sino coherencia con la razón que pide razón de sí misma. Es cuestión de razón, tensada entre biología y espíritu.

6 Davies, P., The Mind of God: The scientific basis for a rational world, Simon/Schuster, NY, 1992, pp. 9-10 y 7 [La mente de Dios. La base científica para un mundo racional, McGrawHill, 1992].

7 Diderot, D., Art. «Encyclopédie», in: Diderot, D. / D’Alambert, J. A., Encyclopédie ou Dictionnaire raisonné des sciences, des arts et des métiers, Paris, 1755, pp. 1751-177: «Une considération surtout qu'il ne faut point perdre de vue, c'est que si l'on bannit l'homme ou l'être pensant et contemplateur de dessus la surface de la terre, ce spectacle pathétique et sublime de la nature n'est plus qu'une scène triste et muette. L'univers se tait; le silence et la nuit s'en emparent. Tout se change en une vaste solitude où les phénomènes inobservés se passent d'une manière obscure et sourde. C'est la présence de l'homme qui rend l'existence des êtres intéressante». 


\section{ENTRE BIOLOGÍA Y ESPÍRITU}

Dentro de esta tensión sostenida se va forjando la aventura intelectual de A. Moya; tensión en la que se juega la cuestión del sentido de la evolución y la pertinencia misma del término. Si la ciencia ha de tener algún sentido, lo tendrá en cuanto cree poder dar cuenta de lo real e intervenir en su transformación, con lo que à rebours el científico mismo se convierte en el sentido de lo real en cuanto conciencia del cosmos. Mutacionismo (transformación/cambio sin dirección) y evolución/progresivismo (cambio con dirección), teleología funcional (diseño funcional, biológica) y teleología direccional (diseño programado, racional), azar y necesidad, naturalidad y artificialidad, selección natural y selección volicional, evolución y transevolución, antihumanismo y humanismo, humanismo y transhumanismo representan polos alternos entre los que se conjuga la cuestión central del sentido, considerada habitualmente como diabolus horribilis e innombrable dentro de la reflexión científica habitual, mientras paradójicamente la propia metodología científica se encuentra confrontada cada vez más con dos hechos: uno (metodológico), la presencia pertinaz de un antropismo (no confundir con el llamado «principio antrópico») que busca y trata de dar razón de la evolución, bajo el supuesto necesario de la racionalidad de la misma que postula teorización y sistema; y dos (ontológico), la emergencia innegable de fenómenos progresivamente complejos que superan el mecanismo de la simple adaptación funcional o el azar ocasional, y parecen apuntar en dirección hacia una cierta necesidad y reversibilidad que se deja recomponer en correspondencia con un programa que habla de direccionalidad y teleología en cierto sentido gradualista, orientadas a procesos de mayor complejidad, mayor creatividad y mayor consciencia. Moya se atreve, sin complejos, a hablar de «proceso de espiritualización» que entiende como «interacción de la materia» hacia una complejidad creativa que deviene exponencial en la consciencia humana y su potencial explícitamente creador. Viene a las mientes como correlato la expresión con que F. Schlegel definía al ser humano: «Der Mensch ist ein schaffender Rückblick der Natur auf sich selbst» [El ser humano es una mirada creadora que la naturaleza dirige sobre sobre sí misma»] ${ }^{8}$. La naturaleza deviene singularmente espiritual cuando llega a ser capaz de autocontemplación, autoconsciencia y autocreación a partir de su metamorfosis humana. Esta cualidad pertenece para Moya a la Vida, que podría entenderse como materia animada, dotada de ánimo, alma o espíritu; o élan autotélico... hasta el punto de ser coextensiva a todos los seres vivos en grado diferente: «El evolucionismo — afirma Moya — ha sido la última aportación intelectual humana que, emanada del materialismo de la ciencia, ha venido a emplazarnos al punto de poder sostener que materia y espíritu son componentes de variación de lo vivo. Es verdad que el origen de la vida es un problema filosófico de primera magnitud, pero no hay esencialmente

8 Schlegel, F., Fragmentensammlungen: Ideen, Fragment 28, S. 258. 
nada espectacular en la transición de lo inorgánico a lo orgánico, excepto el hecho maravilloso de que se haya producido. Es más, experimentos similares han podido originarse en otros lugares del Universo. Materia y espíritu varían en grado; no existen seres sólo materiales o sólo espirituales, simplemente seres sometidos al decurso interno y externo de la evolución. Algunos hemos desarrollado cualidades espirituales peculiares, las mismas que permiten estas reflexiones, pero no podemos hablar de ausencia de espiritualidad en otros seres ${ }^{9}$. Aceptar este planteamiento abierto y tensionado presupone una actitud intelectual abierta, crítica y no dogmática (también se da un dogmatismo cientista - contra el que se rebela Moya- que aborta precipitadamente cuestiones cuyo alumbramiento resultaría incómodo para la "pax scientifica», instalada en una corrección oficialista autocomplaciente y, a veces, poco autocrítica).

\section{Pensar desde la ciencia: Pensar la EVOlución y desde la EVOlución}

Contra el dictum heideggeriano de que "Die Wissenschaft denkt nicht»" [ LLa ciencia no piensa»], Andrés Moya, cada vez con más urgencia y patencia, quiere pensar desde la ciencia. A ese esfuerzo había animado E.O. Wilson con su Consilience y ahora con The Meaning of Human Existence en el ámbito de las ciencias de la vida desde una perspectiva finalmente reduccionista. Pero Moya parece estar más cerca de afirmar que una teoría científica será válida, si -y solo si- no prohíbe pensar, sino si anima a seguir pensando hasta donde la pregunta lleve - criterio socrático de la buena ciencia que defiende el premio Nobel de física R. B. Laughlin ${ }^{11}$, ocupado en las propiedades de la materia que hacen posible la vida, denunciando irónicamente el abuso ideológico del concepto de evolución darwinista y la necesidad de contrastarlo y enriquecerlo con otras ciencias, y a quien parece estar respondiendo Moya con su convicción, convertida en programa de pensar la ciencia y pensar desde la ciencia.

Las ciencias de la vida, a la luz de la teoría de la evolución, están aportando, según Moya, un territorio mestizo que obliga a pensar desde la ciencia cuestiones que parecían patrimonio exclusivo de las humanidades: la naturaleza y sentido

\footnotetext{
Moya, A., Pensar desde la ciencia, o.c., pp. 56-57.

10 Heidegger, M., Was heisst Denken?, in: Id., Vorträge und Aufsätze, Neske, Stuttgart, 1997, p. 127.

11 «Much of present-day biological knowledge is ideological. A key sympton of ideological thinking is the explanation that has no implications and cannot be tested. I call such logical dead ends antitheories because they have exactly the opposite effect of real theories: they stop thinking rather than stimulate it. Evolution by natural selection, for instance, which Charles Darwin originally conceived as a great theory, has lately come to function more as an antitheory, called upon to cover up embarrassing experimental shortcomings and legitimize findings that are at best questionable and a worst not even wrong». Laughlin, R., A Different Universe: Reinventing Physics from the Bottom Down, Basic Books, NY, 2005, pp. 168-169.
} 
del ser humano y de la vida. Las preguntas metafísicas sobre el ser humano y la vida, propias de la tradición humanista, pasan ahora inexorablemente por la ciencia, por los hallazgos recientes en biología molecular y evolutiva, biogénetica, bioquímica, neurobiología, sociobiología, psicología evolutiva, biocomputerización, etc. Entre cientificismo antihumanista y humanismo, entre el desprecio de las humanidades y el desprecio de las ciencias - desprecio basado en la ignorancia mutua y/o en presupuestos ideológicos-, cabe un cientismo humanista, fiel a la mejor tradición intelectual de nuestra cultura. Contra este desencuentro, poco ilustrado, Moya muestra su convencimiento de que se debe y se puede superar ese hiato profundo, a partir, sobre todo, de los avances que la biología evolutiva, y en general las ciencias de la vida, podrían proporcionar como territorio común sobre el que pensar y desde el que pensar.

La teoría de la evolución darwiniana ha transformado radicalmente el ámbito del saber sobre el ser humano, la vida y el mundo. Ya no se puede hacer filosofía, ni ética, ni teología sin tener en cuenta la revolución darwiniana que naturaliza definitivamente la realidad, cualquier realidad, incluida la humana. Las cuestiones «humanísticas» también se pueden explicar desde las ciencias de la vida. Las cuestiones «científicas» son las auténticas cuestiones, dignas de ser pensadas; porque la ciencia ya no es simplemente ciencia "positiva», sino también interpretación, ciencia «hermenéutica» que genera una nueva visión de la realidad, una nueva cosmovisión, que entra en competencia con otras cosmovisiones no científicas. Para nuestro biólogo evolutivo, se está en condiciones de poder invertir el dictum heideggeriano y afirmar resueltamente que la ciencia piensa y que se debe pensar desde la ciencia ${ }^{12}$. El antagonismo entre las dos culturas se supera aceptando la base interpretativa, el marco hermenéutico, que ofrecen las ciencias de la evolución ${ }^{13}$. No cabe ya refugiarse en lo misterioso y «lo inefable» - estrategia habitual para salvar un reducto propiamente humanístico y sustraído a la ciencia positiva-: «La ciencia se convierte, de forma creciente, en permanente ganadora de terreno al mar de lo inefable», porque "desde la ciencia "se puede interpretar" el conocimiento general» ${ }^{14}$.

La inversión demandada - pensar desde la ciencia - descansa, para Moya, en la constatación creciente de que la ciencia no es «una forma más de conocimiento», desacreditada además por la mentalidad humanística como forma particular y metodológicamente reduccionista; sino la forma esencial del conocimiento como tal y base explicativa del funcionamiento de las otras. La ciencia podría convertirse en protofilosofía, en filosofía primera, que el «primer» Moya denomina «metafilosofía» o "metafilosofía científica» ${ }^{15}$ : no una filosofía de la ciencia que otorgaría papel preponderante sobre la ciencia a la filosofía

12 Cf. Moya, A., Pensar desde la ciencia, o.c., p. 71s.; Id., Evolución, Laetoli, Pamplona, 2010, p. 118s.

13 Moya, A., Evolución, o. c., p. 119.

14 Moya, A., Pensar desde la ciencia, o. c., p. 71.

15 Ibid., p. 71 y 73 , respectivamente. 
considerada como metalenguaje, sino una ciencia de la filosofía o metafilosofía científica que piensa la realidad, la verdad y el conocimiento desde la teoría/ hecho de la evolución como punto de partida y clave explicativa de nuestra comprensión del mundo y de nosotros mismos en el mundo, de nuestras ideas y de nuestros comportamientos, de nuestras teorías y sistemas culturales, éticos, artísticos y religiosos. "La ciencia no es "una forma más de conocimiento". Aun cuando existen muchas formas de conocer... creo que la ciencia "es un lenguaje" de una guisa diferente; es más fundamental, más elemental, con capacidad tanto para dar una explicación final de lo inefable, como para poder permitir esos otros lenguajes constituidos por las diferentes formas en cómo se puede explicitar el juego primigenio ${ }^{16}$. La ciencia, según Moya, fiel al viejo ideal de la tradición filosófica/científica griega, intenta «explicar lo inefable», desvelar lo implícito, descubrir la verdad ${ }^{17}$.

La ciencia, contemplada de modo holístico a la luz de la teoría de la evolución y de una filosofía evolucionista, permite a Moya a proponer una síntesis téorica que denomina "monismo de nuevo cuño», una "ontología evolucionista», superadora del dualismo tradicional que, por salvar la singularidad humana, había opuesto materia y espíritu. La singularidad humana se deja explicar como fruto de un proceso naturalista, emergentista y gradualista; y, a la postre, ¿pampsiquista? «El evolucionismo - afirma Moya- ha sido la última aportación inteletual humana que, emanada del materialismo de la ciencia, ha venido a emplazarnos al punto de poder sostener que materia y espíritu son componentes de variación de lo vivo. Es verdad que el origen de la vida es un problema filosófico de primera magnitud, pero no hay esencialmente nada espectacular en la transición de lo inorgánico a lo orgánico, excepto el hecho maravilloso de que se haya producido. Es más, experimentos similares han podido originarse en otros lugares del Universo. Materia y espíritu varían en grado; no existen seres sólo materiales o sólo espirituales, simplemente seres sometidos al decurso interno y externo de la evolución. Algunos hemos desarrollado cualidades espirituales peculiares, las mismas que permiten estas reflexiones, pero no podemos hablar de ausencia de espiritualidad en otros seres ${ }^{18}$. La superación final del dualismo vendrá de un nuevo monismo, heredero de la concepción vitalista de los orígines de la especie, que contemplaba y trataba a la naturaleza como realidad viva. La ciencia - es el sueño de Moya - terminará reconciliando la singularidad humana con la naturaleza misma, pero no para rebajar lo humano sino para dignificar la materia, a cuyo dinamismo creativo pertenecen inherentemente las creaciones de lo que denominamos «espíritu». Entonces, habremos superado definitivamente «la dicotomía materia-espíritu, y habremos alcanzado un monismo de nuevo cuño, dispondremos de una ciencia que progresivamente, partiendo de supuestos

$16 \quad$ Ibid., p. 73.

17 Ibid., p. 74.

$18 \quad$ Ibid., pp. 56-57. 
materialistas, devendrá menos y menos materialista» ${ }^{19}$. Moya no rehúye hablar de espíritu, aunque solo sea por la pregnancia filosófica del concepto, pero renaturalizado y entendido como fruto de la interacción de la materia. «Son, precisamente, la evolución biológica, la historia de la vida y el proceso de complejización e interactividad de lo orgánico los que acaban segregando el espíritu. El espíritu es la interacción de la materia. Obviamente es un destilado de un proceso continuo donde vamos progresivamente ganando espíritu. Los elementos que componen el ámbito de lo espiritual constituyen el núcleo de nuestras características, por ejemplo, la inteligencia, la libertad, la decisión moral o la conciencia del yo. Todos ellos constituyen el ámbito de lo espiritual, allá donde la materia no parece agregar nada a su autonomía, excepto la de su propia génesis y, probablemente, la de su configuración inmediata cada vez que se ejerce un acto de tal tipo, de inteligencia, de decisión moral o de percepción del yo ${ }^{20}$. Pero ir ganando espíritu invita a pensar en una naturalización progresivamente desmaterializada, o en una espiritualización progresivamente transnaturalizada. Ante ese reto intuido en la dialéctica materia-espíritu trata de responder la evolución del propio pensamiento de Andrés Moya.

\section{Pensamiento en evolución: del Sentido de la ciencia a la ciencia como sentido}

La persecución de la verdad que anima el trabajo intelectual de Moya ha devenido una aventura tan honesta que termina coimplicándole a él mismo, hasta el punto de que la cuestión del sentido de la ciencia deviene cuestión del sentido de la evolución e incluso cuestión del sentido de la vida del propio (animal) científico que es el mismo Moya. El científico que puede explicar los orígenes y el proceso de la vida, que puede recrearla y podría incluso crearla, debe poder explicar el porqué y el para qué de su misma vocación científica tensionada entre la voluntad de conocer y la voluntad de poder. La verdad perseguida por la ciencia, arrancada al ámbito de lo inefable, consiste para Moya en reconocer el poder de la ciencia como la revelación última del dinamismo creativo que anima la vida desde el inicio hacia una complejidad creciente en la que podría perseguirse la racionalidad de lo real y la realidad de la racionalidad. Suenan ecos no muy lejanos de raciovitalismo orteguiano. La capacidad para reconstruir teóricamente la evolución de la realidad, material e inmaterial, otorga a la conciencia la capacidad de intervenir en lo real hasta el punto de poder innovar o cambiar el curso de la evolución. Y quien es capaz de dar explicación puede dar sentido. Moya está cerca de afirmar un antropismo transhumanista que supera el humanismo antropocéntrico por medio de un transhumanismo noocéntrico: la vida racional como emergencia (pen)última, abierta a nuevas formas de vida transnatural producidas por ella misma.

$19 \quad$ Ibid., p. 57.

20 Ibid., p. 58. 
El mismo Moya describe la evolución de su pensamiento a partir de sus últimos libros, fundamentalmente biofilosóficos, en los que pretende hacer, más que filosofía de la biología, biología de la filosofía, es decir, repensar los grandes temas humanísticos a la luz del pensamiento evolucionista. En las primeras páginas de su libro Naturaleza y futuro del hombre describe los hitos de su itinerario intelectual hasta ese momento, que podríamos denominar «el primer Moya».

- «En Pensar desde la ciencia abogo por el pensar independiente y no cientificista desde la ciencia, reclamando para ella el interés legítimo por entrar en la arena de los grandes asuntos que siempre han interesado al pensamiento occidental. También sostengo la tesis del carácter melancólico del hombre de ciencia que, ahora, queda obviada al plantear una solución, de corte científico, al nihilismo que supone el sabernos bien totalmente determinados o bien totalmente solos. Finalmente reivindico, [al igual que haré aquí de forma todavía más exigente,] un cierto regreso a la ciencia académica y a la investigación independiente y públicamente costeada».

- «En la segunda obra, Evolución: puente entre dos culturas, defiendo una vía continental, con precedentes bien conocidos en la cultura europea, de lo que sería el regreso a una unificación de saberes científicos y humanísticos. Y la teoría de la evolución es el puente ideal, probablemente el mejor de todos los posibles, para retomar de nuevo esa vieja aspiración ilustrada que_debiera cristalizar en un regreso a los saberes clásicos de la educación, considerando la ciencia como el primero de ellos» ${ }^{21}$.

- En el libro Naturaleza y futuro del hombre pretende ir más allá de la naturalización darwinista y tratar de responder al nihilismo y pesimismo existencial que plantea la elevación del darwinismo o del determinismo génico dawkinsiano a tesis metafísica —el ser humano sería un mero accidente en la historia de la evolución y la vida humana una estrategia al servicio de la supervivencia de los genes- con la tesis de la transevolución y la transhumanización, es decir, un nuevo estadio en la historia de la evolución caracterizado por la capacidad, insospechada hasta ahora, de intervenir directamente en el control y dirección del proceso evolutivo planetario y humano: «Sostengo, frente a tal pesimismo existencial, la tesis de la capacidad de ese ser singular que llamamos hombre de poder subvertir su naturaleza, esté o no gobernada por tales replicadores [sc. génicos]. La historia de nuestra especie es una historia de intervencionismo progresivo, progresivamente más racional, que pone de manifiesto que ha ido dominando, en clave interna, su naturaleza y, en clave externa, la naturaleza de otros entes. La única forma de obviar, además, el nihilismo derivado de conocer que somos productos de la evolución del Universo y, dentro de él, del planeta Tierra, y que estamos aquí igual que podríamos

21 Moya, A., Naturaleza y futuro del hombre, Síntesis, Madrid, 2011, pp. 12-13. 
no estar, es decidir qué vamos a hacer con nosotros mismos, con el buen entendimiento de que disponemos, y saber que dispondremos, cada vez más, de capacidad para intervenir en lo natural... La capacidad para modificar, controlar, detener la naturaleza y su evolución constituye la esencia del proceso de transevolución y transhumanización... la tesis fundamental de la obra es que el hombre representa un punto singular en la dinámica evolutiva del planeta y que el proceso de sabernos entes con naturaleza nos está llevando también a considerar que tenemos capacidad para, introspectivamente, alterarla o modificarla. Nuestra historia con la naturaleza ha sido la de su alteración... Los hitos fundamentales de la cultura de nuestro tiempo nos sugieren mundos y entes radicalmente nuevos y artificiales. La evolución no es que se detenga, sino que estamos en condiciones de orientarla, e ir haciéndolo de forma progresivamente más efectiva ${ }^{22}$.

- Todos estos temas se continúan en el libro Biología y Espíritu, pero matizando tesis anteriores y apuntando a una auténtica Kehre (giro significativo que permitiría hablar de un «segundo Moya»), postulando la aceptabilidad racional de una interpretación de la evolución en clave de proceso de espiritualización creciente del ser humano y del universo, próxima a interpretaciones de raíz teológica, tal como deja apuntado ya en el prólogo: "algunas de las tesis que trato aquí difieren en forma sustancial respecto de concepciones previas».

$\left[1^{\mathrm{a}}\right]$ «La primera tiene que ver con el papel de la ciencia y su relación con otras formas de conocimiento. Así, mientras que en el pasado sostenía la tesis de la competitividad de la ciencia con respecto a otras formas de aprehensión de la verdad o la realidad de los entes, ahora abogo por una necesaria reconciliación entre ciencia y no ciencia, reconciliación que entiendo fundamental, esencial, para dar sentido a la existencia».

$\left[2^{\mathrm{a}}\right]$ «La segunda está relacionada con la naturaleza de la transformación humana y su eventual evolución hacia entes progresivamente menos materiales. En obras previas he estado más próximo a la radical contingencia del ente humano, mayor que la de cualquier otro ente vivo. Ahora esbozo la posibilidad de un proceso de evolución natural de la materia hacia la complejidad, particularmente la de los entes vivos. Ciertas propiedades o características del ente humano, al igual que la emergencia en sí de la vida en su momento, podrían ser razonablemente aceptables aquí y en otros lugares del Universo».

$\left[3^{\mathrm{a}}\right]$ «Finalmente, mientras que en el pasado he llevado a cabo reflexiones, con cierto soporte racional, en torno al futuro del hombre, aquí exploro la eventual convergencia que esa tesis tiene con cosmovisiones y teologías, en la medida en que unas y otras dan soporte o se apoyan en la espiritualización del ente humano y del Universo ${ }^{23}$.

22 Ibid., 11-12 (cursivas primeras nuestras, segundas originales).

23 Moya, A., Biología y Espíritu, Sal Terrae, Santander, 2014, p. 45 (cursivas nuestras). 
Pensar la ciencia y pensar desde la ciencia lleva a Moya a la necesidad de enfrentarse con la pregunta por el sentido del cosmos, de la vida y del ser humano. Ese talante pone a la ciencia ante la responsabilidad intelectual de dar razón de la realidad, hasta donde el método científico permita, y ante la responsabilidad ética de orientar la evolución conscientemente. Amor a la ciencia, por tanto, por amor a la verdad; y amor a la verdad porque solo la verdad (científicamente revelada) otorga sentido a la naturaleza vivida al modo humano.

\section{5. «TERcera REVOlUCIÓN POSTDARWINISTA»: MÁS ALLÁ DE DARWIN}

La relevancia de este proceso, que conduce de la renaturalización darwiniana a la desnaturalización postdarwiniana del ser humano, se intuye en las expectativas novedosas que genera la tecnociencia y que nuestro biólogo/filósofo no duda en calificar de «tercera revolución copernicana» con consecuencias extraordinarias de naturaleza ontológica para el ser humano.

«La tercera revolución copernicana - asegura Moya - va a consistir en continuar, en forma más eficiente y racional que hasta ahora, el proceso de transformación de lo natural. La transevolución y la transhumanización describen esta tercera revolución conceptual, científica y tecnológica, ciertamente, pero también ontológica» ${ }^{24}$. Primero, -recordemos- el desplazamiento de la Tierra de la centralidad cósmica por parte de la teoría heliocéntrica de Copérnico, convertida ahora en planeta orbitando alrededor del sol; después, el desplazamiento del hombre de la centralidad de la naturaleza por la teoría de la evolución y la selección natural de Darwin, convertido ahora en animal genealógica y fisiológicamente, ontogenética y filogenéticamente, emparentado con la naturaleza viva; y, finalmente, el desplazamiento de la animalidad a la artificialidad, debido a la capacidad de intervención, planificación y control del curso de la evolución por parte de la tecnociencia. Esta conciencia postdarwinista de ser, no solo efecto y fruto azaroso de una evolución ciega, sino causa y artífice consciente de una evolución dirigida y controlada por el ser humano, tiene consecuencias epistemológicas en la teoría científica y consecuencias antropológicas en la concepción del ser humano, que pueden articularse en torno a los conceptos de «transevolución» $\mathrm{y}$ «transhumanización».

A) Las consecuencias epistemológicas tienen que ver con la revisión necesaria de la teoría de la evolución y algunos de sus postulados que hoy parecen simplistas. La idea de transevolución implica la revisión de la teoría de la selección natural darwiniana, mutación por azar y adaptación al entorno. La evolución ha devenido compleja. El control del proceso de la evolución natural pasa a manos del animal humano y abre un futuro incierto, tan prometedor

24 Moya, A., Naturaleza y futuro del hombre, o.c., p. 186 (cursivas nuestras). 
como alarmante, para la biosfera y para la especie humana. Podríamos estar asistiendo a la rebelión del ser humano contra los determinantes ciegos de su destino y al advenimiento de un nuevo reino de libertad y creatividad, más allá de la naturaleza biológica y sus dictados. Somos animales, pero (cada vez más) desnaturalizados, podríamos decir utilizando un oxímoron. Se nos antoja interpretar la idea de transevolución de Moya como el culmen y cierre del bucle humanista de Pico della Mirandola («Proteus», "homo plasticus sive creator»: plasticidad y autocreación), del programa baconiano de la «nueva ciencia» («regnum hominis»: scientia et potentia coincidunt: ecuación saberdominio-progreso), del espíritu cientista comteano (la era de la ciencia como estadio final del progreso histórico y triunfo del espíritu positivo) y del vitalismo nietzscheano («Übermensch»: superhombre como autocreación en el espíritu del niño y el artista que recrea la realidad). Una síntesis que mezcla motivos «cientistas» y motivos «humanistas» bajo el leitmotiv de la potencialidad autoorganizativa, autotélica y autocreativa de la naturaleza, especialmente de la naturaleza «científica» humana.

Como científico humanista que es, en el sentido de reconocer a las humanidades legitimidad gnoseológica, Moya no se resigna a ceder la última palabra a la explicación determinista de la conducta humana. Los replicadores dawkinsianos no tienen la última palabra. Estamos paradójicamente determinados a la indeterminación y cada vez más, porque podemos hoy (y en el futuro), más que nunca, ser artífices de nosotros mismos y de nuestro destino. De lo contrario habría que aceptar un pesimismo nihilista contra el que, no solo intuitivamente, sino también tecnocientíficamente cabe resistirse: «Tanta darwinización conduce necesariamente al pesimismo de que ni nosotros ni el mundo somos algo que esté en nuestras manos modificar o transformar. Desde la tesis de la darwinización de nuestra naturaleza, como la de cualquier otra entidad biológica, no somos más que un producto que maximiza el éxito de supervivencia de nuestros replicadores. Llegar a semejante tesis es aceptar cierto pesimismo vital al poner nuestro destino en manos ajenas, por internas que sean ${ }^{25}$. La libertad no es una pura ilusión mientras los genes persiguen su ganancia particular, su multiplicación y supervivencia. Creerlo así supondría incurrir en un fatalismo ciego que suplantaría vía naturalización a la anterior deidad y su designio oculto. No se sale del determinismo teológico con otro determinismo, ahora biológico. Su crítica a Dawkins es contundente: «El giro copernicano - afirma en Naturaleza y Futuro del Hombre- al que el proceso de naturalización de Darwin nos condujo - y que culmina con las tesis sobre el poder de los replicadores a múltiples escalas, no sólo las biológicas sino también las culturales y las sociales-, sólo puede subvertirse con otro giro de similares características. De otra forma estamos abocados al pesimismo existencial y al nihilismo. El poder de los replicadores como fuerzas ciegas que no se avienen a consideración alguna, excepto a la de su perpetuación,

25 Moya, A., Naturaleza y futuro del hombre, o. c., p. 184. 
reemplaza el control que las deidades han venido ejerciendo sobre nosotros a lo largo de la historia. No deja de ser paradójico observar cómo el desvelamiento de lo mítico e inefable - aquello que nos ataba y frente a lo que no podíamos más que rendirnos - nos dispone ahora en una situación similar, o si cabe peor, porque ahora es conocido lo que nos ata y controla. Sabemos, en una palabra, lo que los replicadores pretenden. Pero en la medida en que no podemos actuar sobre ellos, estamos sujetos a su dictamen ${ }^{26}$.

Del «ni diseño ni diseñador», pasando por el «diseño sin diseñador», se acaba por desembocar de nuevo en el «diseño con diseñador», aunque ahora secularizado e inmanentista, en una doble alternativa: el diseño diseñado por la intencionalidad de los genes o el diseño diseñado por la intencionalidad del ser humano. Moya se apuntaría a esta segunda opción ${ }^{27}$. Pareciera que estamos a punto de subvertir el «orden» natural y biológico e imponerle una finalidad y un sentido (teleología) exclusivamente humanos. No un teleología natural, sino una teleología "volicional», como quiere Wilson: We are about to abandon natural selection, the process that created us, in order to direct our own evolution by volitional selection - the process of redesigning our biology and human nature as we wish them to be"28. Vivimos ya en una nueva época: la era de la transevolución y de la transhumanización, más allá de Darwin y Dawkins. La tesis de Moya es tan clara como valiente por crítica con la concepción estándar de la teoría de la evolución: «El pesimismo darwiniano nos sugiere que es puro autoengaño suponer que tenemos capacidad para intervenir sobre los replicadores dawkinsianos. Pero: ¿lo es realmente? La tesis que deseo defender aquí es la contraria, a saber: que el proceso de evolución natural tiene un límite; se contiene o se controla de forma creciente con el inicio por nuestra parte de la transevolución y la transhumanización ${ }^{29}$.

B) Las consecuencias antropológicas tienen que ver con la idea de transhumanización. Esta idea devuelve al homo sapiens sapiens a la centralidad antrópica moderna, noocéntrica y tecnocientífica. El homo sapiens tiene un poder capaz de subvertir la naturalización. Subversión de lo natural significa rebelión, no solo contra el determinismo dawkinsiano, sino contra el pesimismo nihilista al que aboca: «Si el naturalismo... impregna de forma más o menos consciente toda nuestra trayectoria vital, urge pensar si la artificialización podrá o no subvertir el orden, desconocido y difuso, aunque cada vez menos, que la naturalidad impone. Las consecuencias son importantes desde un punto de vista ontológico, porque cabe pensar la posibilidad de imaginar un mundo no darwinizado o, dicho de otro modo, un mundo transevolucionado

26 Ibid., 184-5.

27 «La única forma de superar esta situación sólo puede venir por vías naturales, de nuevo", Ibid., 186.

28 Wilson, E. O., The meaning of human existence, Liveright Publishing Corporation (Norton and Company), NY/London, 2014, 14, passim.

29 Moya, A., Naturaleza y futuro del hombre, o. c., 185. 
$y$ transhumanizado donde lo natural se subvierte ${ }^{30}$ - defiende Moya. Y no solo se refiere a la intervención sobre la naturaleza exterior (algo que el homo sapiens viene haciendo desde el neolítico), sino también a la intervención racional y consciente sobre la propia naturaleza; intervención que podría cambiar su estatuto ontológico, llegando incluso hasta la generación de nuevas especies no humanas, posthumanas o transhumanas: "Existe la posibilidad de la alteración del estatus ontológico de nuestra especie en una suerte de ejercicio de evolución sobrevenida, controlada, la cual en modo alguno es una continuidad de la evolución biológica sino, en todo caso, de su progresivo aminoramiento y eventual reemplazamiento por un modo de intervencionismo racional, transevolutivo» ${ }^{31}$. El futuro surgido de una intervención racional, creciente y deliberada será un futuro transnaturalizado, un nuevo estadio en la historia de la evolución (cada vez más «humana» por menos determinada biológicamente): «Los transhumanos particularmente no van a ser seres naturales y, en todo caso, podrán dictar su destino de forma plena, pues no estarán sometidos al díctum de su naturaleza genético-biológica... no serán sus genes los que jueguen con ellos, sino ellos quienes jueguen con sus genes. En la medida en que esa naturalidad sea subvertida, dominada, comprendida, modificada, estamos hablando de un estadio de la historia de la vida en el cual el hombre será superado, un estadio de transhumanización... En él, la socio-cultura, aunque persistiendo, tendrá menos relevancia que lo natural transformado en la conformación y organización de la sociedad futura» ${ }^{32}$.

\section{RESERVA «HUMANISTA» CONTRA LA «CIENCIA FAÚSTICA»}

Y, sin embargo, el biólogo/filósofo advierte contra el intervencionismo arbitrario de una ciencia «faústica, basada en el experimento del a ver qué pasa» ${ }^{33}$, una tecnociencia que, creyendo disponer de un conocimiento último sobre la naturaleza de las cosas y, por tanto, de una teoría final, se atreve a intervenir irresponsablemente, guiada únicamente por el prurito faústico de poder. Distingue, siguiendo a Castrodezza, dos tipos de ciencia, la «ciencia faústica» y la "ciencia prometeica» ${ }^{34}$. La ciencia faústica se caracterizaría, podríamos decir, por una desmesura epistemológica (omnisciencia) y por una supuesta neutralidad ética (omnipotencia del imperativo técnico), mientras que la ciencia prometeica se caracterizaría por una mesura epistemológica basada en el racionalismo crítico y en la responsabilidad social y ética. Pero un conocimiento total es algo todavía muy lejano, dada la evidencia creciente

\footnotetext{
$30 \quad$ Ibid., 190 (cursivas nuestras).

Ibid., 195 (cursivas nuestras).

Ibid., 191-2 (cursivas nuestras).

Ibid., 171 (cursivas originales).

Vide: Moya, A., Naturaleza y futuro del hombre, o. c., 21, 30, 171.
} 
de una complejidad inabarcable en todos los órdenes de conocimiento y de los propios límites epistemológicos del conocimiento humano. Moya es consciente del carácter provisorio de las teorías científícas y sus resultados: «Toda la tecnociencia del momento, o muy buena parte de ella, está montada sobre teorías científicas que se nos presentan como más o menos acabadas, lo que no deja de ser una burda apreciación de lo que acontece en realidad. La ciencia del momento ha descubierto que el mundo está transido de fenómenos de complejidad emergentes, algo que no se circunscribe al dominio de lo vivo y lo mental. Toda la física moderna nos muestra, también, la presencia de complejidad emergente» ${ }^{35}$. Y ello, además, debido no solo a la condición metodológicamente limitada de la ciencia —reduccionismo positivo-, sino también por la naturaleza misma de toda emergencia -indeterminación ontológica-que hace «imposible predecir los cambios cualitativos que causarán hechos menores en otros de mayor envergadura e implica la imposibilidad de controlar los fenómenos», dirá Moya con Laughlin a quien cita en Naturaleza y futuro del hombre ${ }^{36}$. $\mathrm{Ni}$ en el ámbito de la genómica ni en el campo de las neurociencias (conciencia) contamos con conocimiento exhaustivo y certeza absoluta sobre la naturaleza y procedimientos propios de esos campos, ni con capacidad para hacer predicciones seguras sobre los resultados de un intervencionismo precipitado e irresponsable (a pesar del optimismo cientista injustificado de Dawkins: «I am my genome» o de Seung: «I am my connectome ${ }^{37}$ ). Una cierta querencia profesional, común a los científicos de la vida, parece aconsejar una reserva conservacionista cuando de la vida, y especialmente de la vida humana, se trata. Nadie expresa este «deber sagrado» de fidelidad a la naturaleza heredada de modo tan enfático como E. O. Wilson en su libro The Meaning of Human Existence, donde defiende la "preservation of biological human nature as a sacred trust ${ }^{38}$. Una ciencia seria, que solo puede ofrecer probabilidad estocástica y no predicción exhaustiva, no debiera ponerse al servicio de operaciones de calado cuya reversibilidad no estuviera garantizada; porque «... sería temerario, a día de hoy, sostener que estamos en condiciones de proceder con intervenciones de amplio calado sobre nuestro genoma o sobre nuestro cerebro» ${ }^{39}$. Estamos lejos de poder disponer de una

35 Ibid., 169. Y continúa: «Los métodos de la ciencia, de algunas ciencias, nos han desvelado los secretos de una panoplia de fenómenos simples, pero lo cierto es que la mayor parte de ellos, los que quedan por desvelar, los más medulares al tipo de intervencionismo que reclamamos, son intrínsecamente complejos. Hemos tenido que esperar mucho para poder articular teorías sobre la complejidad, y prácticamente nos encontramos en sus albores».

36 Laughlin, R. B., Un universo diferente. La reinvención de la física en la edad de la emergencia, Katz Editores, Madrid, 2007, cit. in: MoyA, A., Naturaleza y futuro del hombre, o.c., 172 .

37 SEung, S., Connectome: How the brain's wiring makes us who we are, Houghton Mifflin Harcourt, 2012.

38 Wilson, E. O., The Meaning of Human Exitence, Liveright Publishing Corporation (Norton\&Company), NY, 2014, p. 60 (cursivas nuestras).

39 Moya, A., Naturaleza y futuro del hombre., 173. 
teoría final de casi nada, por más de que contemos con mucha ciencia y muchos conocimientos particulares sobre campos específicos que se pueden dar por válidos (componentes de la materia, leyes de la mecánica cuántica, evolución biológica, código genético, computerización del cerebro, etc), mientras operan en ámbitos de actuación circunscritos a los límites definidos por las respectivas teorías específicas; pero no disponemos de una teoría final que diera cuenta de la complejidad, por ahora irreductible, de la realidad en general y ni siquiera de la materia viva ${ }^{40}$. Sabemos poco de mucho y mucho de poco, podríamos decir en lenguaje ordinario. Moya, incluso, va más allá: "Y, en todo caso, asumiento una presencia en el mundo físico de los teoremas de Gödel y derivaciones posteriores, hemos de ser conscientes de que la disponibilidad de las leyes, las reglas y todos los componentes que intervienen en un determinado fenómeno no garantizan su control absoluto. Cierta indeterminación es previsible que podría estar en la base de futuras emergencias y nuevos fenómenos ${ }^{41}$. Por eso, contra la desmesura ontoepistémica de un pretendido conocimiento exhaustivo (omnisciencia) y contra la supuesta neutralidad axiológica del imperativo técnico (omnipotencia), postula, por una parte, la necesidad urgente de una ciencia prometeica, basada en la mesura epistemológica del racionalismo crítico, intelectualmente antidogmático y éticamente responsable, especialmente cuando se trata de actuaciones sobre la especie humana; y, por otra parte, apela a la necesidad de poner en escena un "pensamiento múltiple», para «introducir la historia, la sociología, aquellas políticas que en su momento adoptaron decisiones sobre supuestas bases científicas que resultaron ser auténticos atentados contra la inteligencia $\mathrm{y}$, por descontado, contra la dignidad humana de los seres masacrados ${ }^{42}$. Entre otras cosas, añadimos, porque, desde el punto de vista epistémico, una teoría final significaría el final de la teoría - la certeza absoluta es un objetivo deseable, pero indisponible-; y, porque, desde el punto de vista ético, intervenir irresponsablemente en la alteración de la naturaleza, humana y no humana, a partir de una teoría insuficiente podría significar el final de la naturaleza y de la humanidad. E. O. Wilson aconseja promover las humanidades, aquello que nos hace humanos,

40 Moya: «Pero la certeza en ciencia debe recorrer todavía un largo trayecto para determinar las leyes particulares que operan en cada una de las fenomenologías emergentes que constituyen esa realidad poliédrica que son los seres vivos», Ibíd., p. 171. En Pensar desde la ciencia hace afirmaciones de este calado: «la realidad será eternamente inasible», «no hay realidad aprehendida en su totalidad», p. 50; «Por definición no se puede fabricar una teoría acabada del todo, una teoría científica, porque no podemos ser tan pretenciosos como para pensar que podamos llegar a la realidad de una teoría final, por más plausible que nos lo presenten algunos físicos teóricos», p. 34. «... la ciencia es una forma limitada, aunque sin límite reconocible, de conocimiento de la realidad. Por lo tanto, su método no puede brindar respuestas definitivas, o por lo menos definitivas para los individuos», 51 .

41 Moya, A., Naturaleza y futuro del hombre, o.c., 187; cf. p. 172. Desarrollos más amplios de las teorías de la complejidad y sus consecuencias para la biología evolutiva pueden seguirse en El cálculo de la vida.

${ }_{42}$ Ibid., 171. 
y no enredar irresponsablemente en la fuente de la vida que considera como el único y verdadero potencial del futuro humano ${ }^{43}$. Pero, mientras Wilson se pronuncia a favor de un conservacionismo/conservadurismo naturalista - no renunciar a la «naturaleza humana biológica» heredada-, Moya se inclina más decididamente por un progresismo/evolucionismo transnaturalista que oscila entre el entusiasmo cientista transhumanista, por una parte, que le impele a afirmar con rotundidad el carácter intervencionista de la condición humana hasta el punto de columbrar la culminación del sueño de la autorrealización perfectiva (fausto), a partir de las posibilidades ofrecidas por las nuevas tecnociencias, o incluso la creación de nuevas especies de antropoides (cyborg); y, por otra, la melancolía humanista que mantiene como reserva crítica la experiencia de la contingencia insuperable de la humana condición (Prometeo caído). En esta tensión se juega la redefinición de la singularidad del animal humano y el sentido de su existencia.

\section{PENSAR (DESDE) LA VIDA}

\section{EVOLUCIÓN Y ESPIRITUALIDAD}

En el libro Biología y Espíritu (2014) ${ }^{44}$ reconoce Moya que nos encontramos con el hecho de que la única especie capaz de reconstruir su historia evolutiva es el hombre y, por ello, la única que se pregunta por el sentido o sinsentido de dicha consciencia. La teoría de la evolución darwiniana puede explicar, a través de la selección natural, la común genealogía de nuestra especie con un ancestro compartido por todos los seres vivos (al menos, eucariotas), las mutaciones debidas al azar y la adaptación al medio, la supervivencia y reproducción de los más aptos, las diferencias de grado en los phyla y poco más. Pero las ciencias recientes (biología molecular y poblacional, bioquímica y genética) ponen en evidencia que el proceso de la vida tiende a una progresiva complejidad, a emergencias creativas que no se explican en términos exclusivamente darwinianos, a la presencia de necesidad creciente y no solo de azar para poder dar cuenta de los procesos de autoorganización pertinaces, a la constancia de un dinamismo continuo que apunta a diversificación permanente y complejidad ascendente que culmina en la conciencia como hecho evolutivo que demanda sentido. Moya — si lo interpretamos correctamente- reconoce que contemplar

43 Wilson, E. O., The Meaning of Human Exitence, Liveright Publishing Corporation (Norton\&Company), NY, 2014, p. 60 (cursivas nuestras): «...I hereby cast a vote for existential conservatism, the preservation of biological human nature as a sacred trust. We are doing very well in science and technology. But let's also promote the humanities, that wich makes us human, and not use science to mess around with the wellspring of this, the absolute and unique potential of the human future».

44 Moya, A., Biología y Espíritu, Sal Terrae, Santander, 2014. 
el hecho de que la evolución natural haya engendrado la conciencia obligaría a preguntarse honestamente por la cuestión del sentido de la conciencia de esta historia que la ciencia revela, más allá (o precisamente por eso) de que su origen haya sido natural, azaroso y selectivo. ¿Por qué o para qué hemos llegado a ser entes racioespirituales? ¿De qué nos sirve? ¿Qué hacer con nuestra inteligencia? Responder que la inteligencia juega un papel funcional, como cualquier otra herramienta evolucionada, al servicio de necesidades adaptativas al medio y del medio a nuestras necesidades, no es sino afirmar algo obvio. Pero la capacidad de intervención del animal humano ha devenido crecientemente inadaptativa e incluso biológicamente disfuncional, ordenada no únicamente al servicio de intereses de mera supervivencia biológica, sino al servicio de otros intereses que responden a otras necesidades y otras lógicas que incluso pudieran resultar contrarias a la propia supervivencia, como la lógica de saber, la lógica de poder o la lógica del amor. Lujos innecesarios, excesos evolutivos ${ }^{45}$. La propia ciencia ha generado una nueva realidad, la realidad del pensamiento y su producto autónomo, el mundo del conocimiento y del espíritu, la ciencia como transcendencia. Que la evolución haya engendrado la singular conciencia humana debiera tener algún sentido, además de un significado pragmático, si no se renuncia a la inteligibilidad de lo real como supuesto necesario para la misma ciencia. Moya no renuncia a esto, fiel a la tradición filosófica, aunque repensada e interpretada desde la ciencia. ¿En qué sentido se podría hablar de trascendencia desde la propia ciencia? La ciencia trasciende, en un primer sentido, en tanto va más allá del ente concreto y desvela su verdad oculta (acepción platónica de la verdad como aletheia, desvelamiento); la ciencia trasciende, en un segundo sentido, en tanto va más allá de la esencia natural de los entes y crea deliberadamente otros (poiesis/ techne, acepción tecnocientífica), trascendiendo incluso la naturaleza externa y la naturaleza propia. Tanto si se considera al ser humano como producto final o producto singular de la evolución, el hecho es que el hombre se rebela contra la esclavitud génica y puede intervenir incluso sobre los genes. ¿Se han equivocado de estrategia los genes dawkinsianos, geniecillos ocultos que nos utilizan para autoreplicarse, mientras nos permiten vivir ilusoriamente una apariencia de libertad y conciencia? ¿Han generado los genes la posibilidad de que la ilusión se convierta en realidad? Pero en ese caso un nuevo salto cualitativo se está produciendo desde la propia ciencia, la conciencia del hecho y la trascendencia del mismo. Transevolución y transhumanismo representarían desde esta óptica la trascendencia naturalista del espíritu sobre la misma naturaleza que en el ser humano deviene autotrascendencia consciente, naturaleza autotrascendente. "El espíritu es la interacción de la materia», reconoce Moya ${ }^{46}$. Esa interacción, crecientemente compleja, ha producido el «espíritu», experiencia explicable, para Moya, en su génesis y configuración desde una perspectiva exclusivamente

45 Vide Nogués, R. M., Neurociencias, espiritualidades y religiones, Sal Terrae, Santander, 2016.

46 Moya, A., Pensar desde la ciencia, o.c., 57, 58. 
naturalista: «Son, precisamente, la evolución biológica, la historia de la vida y el proceso de complejificación e interactividad de lo orgánico los que acaban segregando el espíritu»; pero constituyendo el ámbito de lo espiritual (inteligencia, libertad, decisión moral, conciencia del yo) como un ámbito «donde la materia no parece agregar nada a su autonomía ${ }^{47}$, como emergencia cualitativamente diferente que aporta la propia conciencia de evolución y con ello la posibilidad de explicarla, controlarla y dotarla de sentido; un sentido que cabe interpretar desde la libertad de interacción consciente, desde ese "espíritu» creativo que ha aparecido en la historia evolutiva del cosmos, que podría interactuar ahora más allá del puro azar y la necesidad. «Parece... que la inteligencia es un carácter sin referente adaptativo, y si lo tiene, se trata de uno de reciente adquisición y que nos está jugando tanto buenas como malas pasadas» ${ }^{48}$.

\section{Ciencia, espiritualidad y Sentido}

Naturalizar el espíritu —siguiendo nuestra interpretación- podría significar para Moya, desde la perspectiva de la transevolución, espiritualizar la naturaleza, entendida como materia que se autotrasciende. Y espiritualidad podría entenderse como la tendencia a una complejidad creciente que conduce a la autoconciencia y la autotransformación. Materia y espíritu representan categorías complementarias dentro de una concepción monista de la realidad entendida como naturaleza viva y creativa. El avance de la ciencia permite imaginar «una ciencia que progresivamente, partiendo de supuestos materialistas, devendrá menos y menos materialista», reconoce $\mathrm{Moya}^{49}$. Ni Nietzsche hubiera soñado que el superhombre pudiera llegar de manos de la ciencia, al menos de manos de la ciencia moderna contra la que expresaba conocidas reservas. Incluso nuestra desaparición en aras de nuevas creaturas, creadas «a nuestra imagen y semejanza», más perfectas y más complejas, podría interpretarse - a falta de otros criterios extracientíficos- como un episodio más de la misma evolución que no cabría en principio lamentar especialmente.

Sin embargo, la cuestión del sentido preocupa a Moya, tanto del sentido científico como del sentido existencial que entiende como "tensión esencial»: «La perplejidad que provoca la existencia es una constante a lo largo de la historia. El pensamiento sin asideros sobre nuestra existencia conduce a la angustia y la soledad. Tal ejercicio no va asociado a logro positivo alguno, y los logros positivos de la razón no sirven para satisfacer las inquietudes suscitadas por el pensamiento sobre el sentido de la existencia» ${ }^{50}$. Enfrentarse a la cuestión del sentido puede conducir para Moya a cuatro posturas: afirmar

\footnotetext{
$47 \quad$ Ibid., 58.

$48 \quad$ Ibid., 32.

$49 \quad$ Ibid., 57.

$50 \quad$ Ibid., 32.
} 
el absurdo, afirmar el sentido (desde el humanismo o desde la religión), suspender la cuestión o evitar/distraer la cuestión. Pero, en cualquier caso, «indefectiblemente estamos abocados, por la naturaleza de nuestra inteligencia, a pensar en el sentido de la vida» ${ }^{51}$. En escritos intimistas como Pensar desde la ciencia, donde se deslizan confesiones sobre lecturas preferidas del autor, no es casual que cite a Unamuno, Kierkegaard o Nietzsche; y que considere al científico serio (él mismo) como "experimentador intimista», imbuido de un talante trágico, condenado a la melancolía y soledad existenciales.

Nada más elocuente que el lamento dramático que produce la conciencia de la cuestión del sentido y la impotencia de la racionalidad para responderla -lamento que Moya hace suyo con estas palabras: "Qué triste sino el haber llegado al punto de poder plantearnos el sentido de la vida y admitir que hay un océano inasible, aunque delimitado, que contiene todo ese conjunto de importantes asuntos de los que no podemos hablar. Estemos o no solos en el Universo, la realidad es que nuestra propia racionalidad, entendida ésta como la práctica de su producto más elaborado, la ciencia, nos pone ante una soledad existencial profunda. ¿Cuál? La de no saber qué hacemos aquí, y me resulta indiferente el que mi propia racionalidad me diga que no tiene sentido el preguntarme tal cosa. El sentido tiene sus límites, pero yo siento que no los tengo. La diferencia está cubierta por el océano de incertidumbre, ese que tiene múltiples componentes sobre los que nada podemos decir» ${ }^{52}$. La conciencia de existir, que es algo más, y diferente, que la conciencia de ser algo y de la conciencia de ser especie o de ser individuo, demanda sentido. El sentido al que apunta Moya, desde la racionalidad científica y la contingencia radical de nuestra naturaleza, es el sentido nietzscheano de autosuperación y autocreación, pero postnihilista. Si no se quiere incurrir en el nihilismo, y se quiere responder honestamente a la cuestión de la presencia de la cuestión del sentido del sinsentido al que arroja la propia racionalidad científica, entonces se puede encontrar una respuesta en la ciencia que también permite, además de la plena conciencia de la autocreación, la conciencia de poseer los medios para su realización. La espiritualidad se traduce en autosuperación y autotrascendencia. Las alusiones explícitas a Nietzsche no dejan lugar a duda, aunque reinterpretado desde las ideas de transevolución y transhumanismo. Nietzsche revisado científicamente daría como resultado, para Moya, rescatar lo que entiende como el significado profundo de las tesis del filósofo vitalista sobre el superhombre: «nuestra radical y creciente capacidad de autointervención» ${ }^{53}$.

\footnotetext{
${ }_{51}$ Ibid., 37. Cf. Ibid., 26, 38, 100 passim.

52 Ibid., 26-27.

53 Ibid., 71. Cf. Evolución...: donde, dando un paso más, avanza la hipótesis del cyborg como encarnación proléptica del superhombre nietzscheano. La combinación de biología y robótica, computación y nuevos materiales ofrece la posibilidad de que el cyborg represente «un modelo futuro retroactivo sobre el que deberíamos reflexionar, entre otras cosas porque puede constituir, como nunca hubiera imaginado el mismo Nietzsche, la viva imagen, en términos biológicos y éticos, de lo que él atisbó como superhombre», 137.
} 
Y, aunque no compartiría la postura nietzscheana de estar «más allá del bien y del mal» y aplicarla a la ciencia, uno nota que la perplejidad y la desazón por el futuro del hombre que alimenta la búsqueda de sentido de Moya requiere de algo más que solo ciencia fáustica y, ni siquiera o no solo, «más y más ciencia» prometeica $^{54}$, como exigía en Naturaleza y futuro del hombre.

\section{ACERCAMIENTO ENTRE CIENCIA Y RELIGIÓN}

Observamos un vaivén, no resuelto del todo, propio de la doble alma de científico y filósofo en que habita Moya, entre humanismo y cientismo que, más allá de declaraciones explícitas a favor de su superación, no termina de estabilizarse. Pero entendemos que esa tensión es, precisamente, lo que convierte sus escritos en testimonios de una búsqueda incesante y honrada en los límites a los que la razón arroja. Reclama valores éticos en el científico y en el ejercicio de la ciencia, pero no justifica desde dónde y por qué; desde luego, no desde la misma ciencia. Quizá, por eso, en su escrito Biología y Espíritu nos sorprende verle considerar como compañeros de aventura intelectual a científicos creyentes (Teilhard, Dobzhansky, Tipler), valorando no precisamente su condición inequívoca de científicos, sino lo que desde su cosmovisión creyente aportan de novedad a la concepción naturalista de la evolución. Moya encuentra similitudes entre su postura y la de sus mentores creyentes en el estado actual de su reflexión sobre el futuro del ser humano - aunque interpretándolas desde el naturalismo ateo al que no renuncia-. Quizá no sea casualidad que, convencido como está de que la ciencia prometeica (búsqueda paciente, seria y honesta de saber) no debe ceder ante la ciencia faústica (prepotencia cientista justificadora de un intervencionismo precipatado e irresponsable), abogue en este escrito, y remitiéndose al pensamiento de los autores arriba citados, por un "acercamiento entre ciencia y religión», viéndose sorprendido él mismo de encontrarse próximo a posturas evolucionistas de autores cuyo trabajo científico ha sido inspirado por convicciones religiosas. La razón que aduce es la siguiente: «¿Por qué apuesto por la tesis del acercamiento? Puede que sea debido a tener en consideración un muy sano principio en el campo de la ciencia: la generalización o el desarrollo de teorías de gran calado o capacidad explicativa. Probablemente nos proporcione una mayor satisfacción intelectual (y quién sabe si existencial también) poder dar con una explicación razonable que combine sectores alejados o contrapuestos del pensamiento en torno a las relaciones entre la materia y el espíritu, entre la ciencia y los valores ${ }^{55}$.

Otorguemos el valor que se merece a esta confesión por lo que implica: (1) primero, apelación a un concepto de ciencia abierto y dialogante, por coherencia interna con un criterio metodológico, propio de la ciencia honesta,

54 Moya, A., Naturaleza y futuro del hombre, o. c., 169.

55 Moya, A., Biología y Espíritu, o. c., 148. 
que busca teorías de gran calado, es decir, epistémicamente inclusivas, incluso de visiones no directamente científicas que pueden inspirar la elaboración misma de teorías más completas y más satisfactorias; y (2) porque que, a su vez, el acercamiento entre ciencia y religión puede procurar, no solo satisfacción teórica, sino también satisfacción existencial. Moya no dice más (todavía), pero no dice poco. Su honestidad intelectual de científico/humanista le obliga a llevar la pregunta hasta donde la pregunta lleve, continuando el pathos socrático constituyente de la actitud filosófica honesta. Y la cuestión final a que se ve abocado esta suerte de científico paradójicamente unamuniano, de «científico melancólico», que es Andrés Moya, es la cuestión del sentido de la vida ${ }^{56}$. Moya cree en la ciencia y cree que la ciencia crea la realidad ${ }^{57}$, y que la creación científica de realidad otorga sentido a la vida (cabe esperar, al menos, a la vida del científico). Pero cree también, porque es una condición metodológica y axiomática de la buena ciencia, que la "realidad será eternamente inasible ${ }^{58}$, con lo que si el sentido de la vida consiste en acumular conocimientos y el conocimiento no tiene límite, la cuestión del sentido queda insatisfecha, a no ser en la melancolía del sentido anhelado, pero siempre defraudado. La cuestión del sentido de la vida, resuelta científicamente, conduce únicamente a satisfacer parcial y provisoriamente una demanda «eterna» de conocimiento. Pero un mayor conocimiento no implica necesariamente más bondad o más felicidad. Puede, incluso, conducir a lo contrario, a mayor bajeza moral y a mayor insatisfacción vital. La ciencia no basta para dotar de sentido, como reconoce Moya: «Puesta en toda su dimensión explicativa, la ciencia es una forma limitada, aunque sin límite reconocible, de conocimiento de la realidad. Por lo tanto, su método no puede brindar respuestas definitivas, o por lo menos definitivas para los individuos ${ }^{59}$.

\section{El CIENTífico COMO ANIMAL MELANCÓLICO}

Y es ahí donde al científico honesto, que no renuncia a más verdad y a más sentido, le invade la melancolía. «El individuo deviene melancólico — sostiene Moya con Földényi- cuando su natural incapacidad para entender o darle sentido a su existencia se convierte en algo omnipresente». Reconoce no saber «si afirmar que se llega a la ciencia por melancolía o que la asunción de la ciencia en toda su dimensión genera melancolía en quien la práctica». Lutero venía a afirmar que la ciencia (matemática) convierte al hombre en melancólico (curiosa coincidencia en la época con el famoso grabado homónimo de Durero,

56 Cf. Moya, A., Pensar desde la ciencia, 49-51.

57 «La realidad es producto de la ciencia», «la ciencia es la realidad», MoyA, A., Naturaleza $y$ futuro del hombre, o. c., 200.

58 Moya, A., Pensar desde la ciencia, 50.

59 Ibid., 51 (cursiva nuestra). 
que Moya eligió como portada del libro Biología y Espíritu), del mismo modo que la medicina en enfermo y la teología en pecador. Moya suscribiría la primera afirmación de Lutero: la ciencia convierte al hombre en melancólico. En cualquier caso, reclama la necesidad de recuperar algo que considera perdido en la ciencia actual: «el carácter melancólico del hombre de ciencia ${ }^{60}$, resultante de la necesidad de verdad y conocimiento absoluto experimentada por el científico, que se ve contrastada permanentemente con una realidad «eternamente inasible» y la «ineludible incertidumbre provocada por el desconocimiento, por la incapacidad de explicación integral del todo», y por la conciencia irrenunciable de «la hilazón entre ciencia y reflexión existencial y, por lo tanto, entre el científico y la búsqueda del sentido de la existencia ${ }^{61}$. En la melancolía se reconoce el científico que se toma en serio su vocación investigadora y su condición existencial, el científico que piensa desde la ciencia y se deja cuestionar tanto por sus logros como por sus limitaciones. El científico convertido en filósofo que vive la ciencia como "práctica dubitativa y personal $»^{62}$.

La respuesta a esta cuestión no está escrita en la evolución; pero, al darse la pregunta, se está admitiendo que la evolución ha producido casualmente a un ser que demanda sentido contra el sinsentido que debiera aceptar como natural. La espiritualidad ${ }^{63}$ es un intento de responder a la perplejidad de sabernos mortales, contingentes e irrelevantes y, al mismo tiempo, únicos y lúcidos, capaces de construir relatos de sentido sobre el sentido y el sinsentido. La respuesta tradicional ha consistido en dotarnos de sentido, dotando de sentido a la naturaleza y a la vida, interpretada bien como destino, bien como don, bien como tarea o una mezcla de todo ello. Moya no se resignaría al pesimismo trágico que nos provoca la contemplación de los avatares evolutivos, tampoco a la aceptación gozosa de un designio amoroso revelado en la contingencia del proceso evolutivo - posturas ambas cuya ocurrencia puede justificar desde la teoría poblacional de la desigual distribución de racionalidad y espiritualidad, de modo idéntico a otras cualidades humanas-; sino, más bien, a la posibilidad de convertir en proyecto consciente la conciencia de la soledad existencial sin ilusiones (pseudo)naturalistas ni (pseudo)religiosas. La gestación del ser humano, dicho en estricta ortodoxia evolucionista, no ha sido fruto ni consecuencia de un proyecto evolutivo intencionado y diseñado; pero el ser humano actual, científico, el «homo scientificus» puede y debe, si no quiere sucumbir a la desilusión existencial o a la ilusión religiosa, convertir el proceso de la evolución en proyecto controlado para la aventura venidera del ser humano en el cosmos, marcando el rumbo futuro de su desarrollo (transevolución y transhumanismo). Ese parece ser el (único) sentido posible

\footnotetext{
60 Moya, A., Pensar desde la ciencia, o. c., 49 (tres últimas citas).

61 Ibid., 50-51

62 Moya, A., Evolución, o.c., 148.

63 Cf. Moya, A., Biología y Espíritu, o.c., pp. 156-157. Cf. Moya, A., Pensar desde la ciencia, o.c., 69-70.
} 
(por ahora) para Moya. En este punto va más allá que otros científicos/filósofos anteriores, como Wittgenstein y Pascal, que declararon convencidos que la ciencia no podía responder a las grandes cuestiones existenciales en que se juega el significado de la existencia y condición humanas - recordemos la tan citada advertencia de Wittgenstein hacia el final del Tractatus: «Wir fühlen, dass, selbst wenn alle möglichen wissenschaftlichen Fragen beantwortet sind, unsere Lebensprobleme noch gar nicht berührt sind ${ }^{64}$. Y, aunque evita conscientemente considerar la ciencia como religión ${ }^{65}$, parece depositar su confianza, e incluso su fe en una ciencia «crítica» y responsable, empeñada en la comprensión y en la modificación de la naturaleza humana.

En Moya volvemos a la espiritualidad bajo la única forma legitimada para y por el científico: la contemplación racional y la intervención creadora. El futuro se vislumbra más espiritual por artificial y transnatural que material (nunca espiritualismo sobrenaturalista en Moya); más como creatividad que como repetición, más como conciencia cósmica que como evolución ciega, más como libertad que como determinismo. El sentido, a partir de ahora, estaría inscrito en el cosmos porque nosotros hemos pronunciado su fiat. El sentido radica en leer la historia del cosmos como evolución y la evolución como «proceso de complejidad creciente y espiritualización» que culmina en el hombre entendido como «emergencia particular... claro exponente de un producto de la complejidad creciente que genera inteligencia, pensamiento y espiritualidad»; emergencia que obliga a admitir que, aun pudiendo no haber existido, «lo que no deja lugar a duda es que estamos aquí, que hemos transformado nuestra naturaleza y la naturaleza de los otros entes, y que estamos en camino de transformaciones transhumanizadoras y transevolutivas de mucho mayor calado. Es probable que podamos encontrar un sentido a nuestra existencia aceptando el reto de poner el futuro en nuestras manos ${ }^{66}$. A la ciencia seria y responsable que defiende Moya, a la ciencia que piensa con alma humanista, corresponde comprometerse, para que ese futuro venga de las manos del esforzado y noble Prometeo y no del caprichoso e irresponsable Fausto.

64 Wittgenstein, L., Tractatus logico-philosophicus, WA, Band 1, Suhrkamp Verlag, Frankfurt a.M, 9. Aufl, 1993, S. 85. [Cursiva original].

65 Cf. Moya, A., Evolución, 148: «Pero hemos de cuidar de que la ciencia no se transforme, por ello mismo, en la religión de nuestro tiempo».

66 Moya, A., Biología y Espíritu, o.c., 110 (cursiva nuestra). En otro pasaje de Naturaleza y Futuro del hombre afirma de modo similar: «La única forma de obviar, además, el nihilismo derivado de conocer que somos productos de la evolución del Universo y, dentro de él, del planeta Tierra, y que estamos aquí igual que podríamos no estar, es decidir qué vamos a hacer con nosotros mismos, con el buen entendimiento de que disponemos, y saber que dispondremos, cada vez más, de capacidad para intervenir en lo natural», Moya, A., Naturaleza y futuro del hombre, o.c., 12. 


\section{ObSERVACIÓN CRÍTICA FINAL: ¿VOLUNTARISMO INFUNDADo?}

La actitud del científico voluntarista que intenta desde la ciencia responder a la cuestión inevitable, incómoda y, estrictamente hablando, poco científica del sentido, resulta noble pero injustificada. Los cientistas saben, a fuer de naturalistas, que se encuentran inmersos en una realidad sin propósito y que, por tanto, cualquier intento de dotar de propósito y sentido a la naturaleza no puede venir de la ciencia, porque no puede venir de la naturaleza muda e indiferente. Esperar sentido (racional, moral, estético o religioso) de la ciencia y creer que la ciencia puede otorgarlo, es una actitud voluntarista que no puede fundamentar la misma ciencia. El conocimiento científico no conduce necesariamente a la bondad, la emoción científica no conduce necesariamente a la solidaridad, la lucidez racional no conduce necesariamente a la humildad intelectual y a la contemplación extasiada de la grandeur de lo real. Y a nada de esto renunica el científico sensato. Y ni el conocimiento científico, ni el afán de saber, ni la lucidez racional conducen necesariamente a la felicidad o al «gozo de sabernos existentes», como reconoce Moya en otro pasaje ${ }^{67}$ de Naturaleza y Futuro del Hombre. Pueden contribuir a ello, pero también a lo contrario. Comparte con Castrodeza que «ese camino de desbrozar lo inefable también nos aporta sensaciones contradictorias y puede conducirnos al nihilismo más proverbial, especialmente, cuando por la naturalización del hombre, llegamos a desproveer de sentido sobrenatural a nuestra existencia» ${ }^{68}$. ¿Qué nos queda, pues, si se trata de renaturalizar desnaturalizando (transnaturalizando) al ser humano y no queda más trascendencia que la que la ciencia procura?

La evolución no nos desvela un propósito, pero no nos resignamos a vivir como si no lo tuviera. Tampoco los cientistas convencidos que no quieren concluir en nihilismo filosófico/científico o en pesimismo existencial. ¿Quién o qué nos salvará de la evolución a ninguna parte? ¿De una evolución a la deriva? Desde luego, ni la biología ni la física ni la neurociencia por sí mismas. ¿Un voluntarismo cientista infundado? Aunque aceptáramos que la pregunta por el sentido debiera desaparecer como falsa cuestión, porque la ciencia nos revela que no hay finalidad ni sentido en la evolución; nos esforzamos, no obstante, en encontrar una finalidad y un sentido para la evolución. Porque, de lo contrario, la misma actividad científica, que define al animal humano como animal científico, perdería sentido. Los cientistas no nihilistas, como nuestro biólogo melancólico, quieren creer que el mundo es inteligible, bueno y bello, a pesar de evidencias en contra. No parecen resignarse a seguir narrando la evolución como el cuento de la salvación imposible, el cuento de la historia interminable de una evolución en la que lo que no cuente sea, precisamente, la suerte del animal humano.

67 Moya, A., Naturaleza y futuro del hombre, o.c., 155.

68 Ibid., 155. 
Al final del libro, Biología y Espíritu, apela a liberar la cuestión del sentido de encorsetamientos axiomáticos y prejuiciados de la tradición filosófica y teológica, para reconsiderarla a la luz de la ciencia, donde la espiritualidad puede encontrar ahora acomodo evolutivo: «La espiritualidad es un fino logro, primero, de la evolución biológica, y luego de la cultural, pues proporciona paz, nos aleja del desasosiego. En los albores de nuestra existencia, la espiritualidad debió verse favorecida por la selección natural de un tipo de caracteres frente a esos otros generadores de comportamientos dubitativos, los que asustan por la sensación que produce la soledad de sabernos seres inteligentes, sí, pero únicos en el Universo. La espiritualidad, por el contrario, permite sentir unicidad, trascender el propio yo aislado para formar parte de un todo armonioso, alcanzar la convicción de que existe un significado para el Cosmos, con nosotros incardinados en él. ¿Quién no ha experimentado con grado diverso ese particular sentimiento?» ${ }^{69}$.

El «proceso de espiritualización» creciente al que estamos convocados se traduce para Moya en la capacidad de dotar de sentido a la existencia desde el poder que la ciencia pone en nuestras manos, interviniendo activamente en la configuración de nuestro futuro. Pero queda sin resolver desde dónde y para qué. ¿Desde el topos científico actual que provoca tanto certeza como incertidumbre? ¿O desde el topos existencial que demanda valor y sentido, so pena de sucumbir al pesimismo o arrastrar un desasosiego melancólico incurable, si no se quiere huir de la pregunta? El «científico melancólico» hace de la perplejidad y la incertidumbre acicate para seguir buscando sentido existencial a su propia vocación, mientras el científico al uso se conforma con reducir el sentido de la vida a la acumulación de conocimientos.

Dialogar con A. Moya es gratificante y estimulante, precisamente por su condición híbrida de científico/filósofo, y Biología y Espíritu invita a ello. Como hombre/puente entre las dos culturas, ninguna cuestión humana le resulta ajena. La humildad intelectual en la búsqueda por develar lo inefable, el afán denodado por buscar más verdad y la apertura sincera a completar, con el acercamiento a otras formas de conocimiento y de experiencia, los límites actuales de la ciencia; así como su valentía para cuestionar lo darwinianamente correcto, le convierten en un intelocutor imprescindible dentro del ámbito hispano en el diálogo entre ciencia, filosofía y teología. Aceptemos el reto que nos propone de pensar desde la ciencia y añadamos que ese modo de pensar debe convertirse en un pensar de otro modo, como vienen reclamando con él muchos científicos actuales, que está por hacerse. Siguiendo el consejo de Moya: «De ahí la radical necesidad de la instrucción en la ciencia, pues solo así se podrá evitar, también, caer en los mismos defectos que otrora tuvo la religión cuando detentaba el predominio intelectual e incluso político. Por otro lado, la necesaria instrucción en la ciencia debiera acompañarse con otras formas de conocimiento esencial e intuitivo de los entes, como la poesía y la filosofía. Planteo una enseñanza

69 Moya, A., Biología y Espíritu, o.c., 157. Cf. Moya, A., Pensar desde la ciencia, o.c., 69-70 
en paralelo, y mutuamente enriquecedora, entre ciencia y no-ciencia, y que el individuo perciba que su instrucción en ciencia se hace filosófica o poética, y su filosofía y poesía, científica. Es así como con tal aproximación ganaremos al tiempo en conocimiento y en sabiduría ${ }^{70}$. No otra cosa pretende Moya cuando invita a pensar desde la ciencia, a pensar la ciencia, y a pensar la vida y pensar desde la vida. Será ahí donde el diálogo entre ciencia, filosofía y religión podrá resolverse en fecundidad y sentido compartido, y donde la melancolía del científico podrá transitar, al menos algún trecho existencial, por el camino en el que naturaleza, valor y sentido se puedan reconciliar en el relato evolucionista.

Terminamos con Octavio Paz, otorgando a la intuición poética la última palabra y afirmando, contra materialistas y contra espiritualistas, la necesidad de mantener la apertura inagotable e irreductible de la pregunta originante de la filosofía y la ciencia, la X de la multiplicación y la incógnita, el interrogante de la duda y la pesquisa en que se mueve la investigación y la reflexión de nuestro científico melancólico:

«...somos la intersección, la $\mathrm{X}$, el aspa maravillosa que nos multiplica y nos interroga...»

«...el hombre es el momento en que la tierra duda de ser tierra y el mundo de ser mundo...» allá ${ }^{71}$

«...el hombre no es el que es, célula o dios, sino el que está siempre más

Como Andrés Moya, científico/filósofo tensionado entre biología y espíritu.

Bibliografía de Andrés Moya*

Moya, A. (2014). Biología y Espíritu. Santander: Sal Terrae.

Moya, A. (2014). El càlcul de la vida. València: Publicacions de la Universitat de València.

[El cálculo de la vida, Publicacions de la Universitat de València, València, 2014; The calculus of life, Springer, Heidelberg/New York/Dordrecht/London, 2015]

Moya, A. (2011). Naturaleza y futuro del hombre. Madrid: Editorial Síntesis.

Moya, A. y Peretó, J. (2011). Simbiosis. Seres que evolucionan juntos. Madrid: Editorial Síntesis.

Moya, A. (2010). Pensar desde la ciencia. Madrid: Editorial Trotta.

Moya, A. (2010). Evolución. El puente entre las dos cultura. Pamplona: Editorial Laetoli.

Fontdevila, A. y Moya, A. (2003). Evolución. Origen, adaptación y divergencia de las especies. Madrid: Editorial Síntesis.

Fontdevila, A. y Moya, A. (1999). Introducción a la Genética de Poblaciones. Madrid: Editorial Síntesis.

\footnotetext{
70 Moya, A., Biología y Espíritu, o.c., 72-73.

71 Paz, O., Árbol adentro, Seix Barral, Barcelona, 1987, 130-1.

* Relación completa de publicaciones del autor en: http://www.uv.es/cavanilles/personal/ Andres_Moya/
} 
Moya, A. (1989). Sobre la estructura de la teoría de la evolución. Bbarcelona: Editorial Anthropos.

Moya, A. (1988). Ensayos heterogéneos sobre biología y evolución. València: Publicacions de la Universitat de València.

Moya, A. (1983). Análisis y crítica de la axiomatización de la Biología de J.H. Woodger, Publicaciones de Bioestadística y Biomatemática, 8. Barcelona: Publicaciones y Ediciones de la Universidad de Barcelona.

Diego Bermejo

diego.bermejo@deusto.es

[Artículo aprobado para publicación en enero de 2018] 